\title{
Design, Fabrication and Evaluation of Wheel Operated Sprayer
}

\author{
Shambhu Singh ${ }^{1 *}$, D.Padhee ${ }^{2}$, Suryakant Sonwani ${ }^{1}$, Trishala Sahu ${ }^{2}$ \\ ${ }^{1}$ (FMPE) Scholar, SVCAET \& RS, IGKV, Raipur (C.G), India \\ ${ }^{2}$ (FMPE), BRSM CAET \& RS Mungeli, IGKV, Raipur (C.G.), India \\ *Corresponding author
}

Ke y w o r d s
Boom sprayer,
wheel barrow,
wheel driven pump,
design, performance
evolution,
effectiveness and
efficiency
Article Info
Accepted:
15 December 2019
Available Online:
20 January 2020

Now day's scarcity of labour is creating problem during agricultural operation because in agriculture more labour is required. Pests and weed problems, in crop production are serious both in rain fed and irrigated farms in Chhattisgarh. Farmers are forced to spray insecticides, pesticides and herbicides frequently using manually operated machines, This becomes time consuming poor in application uniformity, laborious, costly and human fatigue is major concern, these problems can be overcome by using manually wheel operated sprayer The objectives of this research saw to manufacture and evaluate wheel operated sprayer. The sprayer was tested both in laboratory and field for the uniformity of application, discharge rate, field capacity and field efficiency and had achieved an application rate of $639.09 \mathrm{l} / \mathrm{ha}$, with coefficient of variation (CV \%) of $2.50 \%$ among the nozzles discharge rate, effective field capacity of $0.075 \mathrm{ha} / \mathrm{hr}$., theoretical field capacity of $0.126 \mathrm{ha} / \mathrm{hr}$. and field efficiency of $56 \%$. Based on the performance result the newly developed sprayer can cover one hectare of land within about an hour with a better spray uniformity.

\section{Introduction}

Plant protection equipment plays a significant role in agricultural field to the productivity of a several crops. Agricultural pests, which include organisms such as fungi, bacteria, viruses, insects, mites, nematodes, weeds and grain-eating birds, that live on and/or compete with plants determine, to a varying degree, if crops can be grown economically in certain situations. Usually agricultural pests inflict considerable damage to crops and represent a significant production constraint. Effective plant protection thus becomes essential to minimize the losses caused and to ensure that full benefit is drawn from other production inputs (Wolman and Fournier, 1987). 
Chemical application has been very successful in pest control but must be handled properly, applied in rationed proportions and spray effectively. Specialized equipment is thus essential for chemical application is the only fully mechanized farming operation. Machines previously developed for chemical application include the knapsack sprayers, the ultra-low volume sprayers and tractor boom sprayers (Liu, 2008).

The wheel is attached to sprocket and the wheel is attached to gear and that sprocket and gear is joined by chain. That assembly is mounted on frame. By push the cycle that pushing pressure developed by rotated wheels. Then the rotation of wheel joined sprocket will be rotated. As well as gear it will be rotate by the assembly of attaching the chain. The gear is attached to wheel so wheel will be rotated by pushing the operator. in this machine four bar mechanism is applied to convert the rotary motion of chain sprocket into reciprocating action for piston to developed pressure inside of air pump used in spray tank therefore this developed pressure release in the form of water vapor through sprayer boom in this sprayer there are three nozzle used and also provide boom frame for adjust the height and width of nozzle according to requirement of crops

I have proposed a wheel driven sprayer, it is a portable device and no need of any fuel to operate, which is easy to move and sprays the pesticide by moving the wheel.

\section{Materials and Methods}

Indian farmers use traditional method, there is large scope for development in agricultural sector. In traditional method weeding process are done by the bull which become costly for farmers having small farming land its time consuming and requires separate setup. The spraying is traditionally done by backpack spryer with labor which requires more human effort, it cover small area, time consuming and low storage capacity. Therefore to overcome above problems, we have design and develop the flexible equipment which will be beneficial to the medium and small scale farmer for the weeding and spraying operations.

Looking to the problem of manual weeding and backload sprayer the current study is planted to remove the backpack and foot spraying techniques, eliminate the human efforts, to decrease labour cost by advancing the spraying method and constant flow of droplets

\section{Design calculation}

Design of frame (Deshpande, 2017)

Length of frame $=$ Centre distance between two sprocket + width of tank + excess

$$
=230+440+570
$$

$=1200 \mathrm{~mm}$

Height of frame $=30 \mathrm{~mm}$

Width of frame $=240 \mathrm{~mm}$

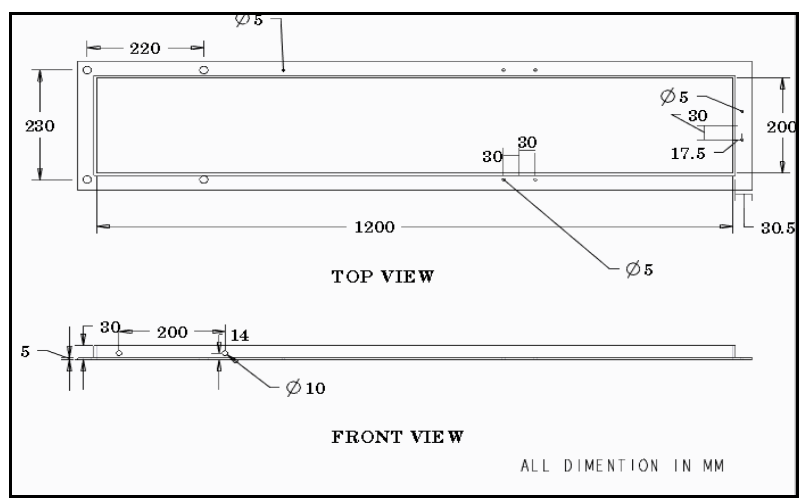

Fig.1 Main frame top view and front view 
Selection of wheel (Deshpande, 2017)

Distance between two plant $=1.25$

Feet $=38 \mathrm{~cm}$

Line covered by one rotation of wheel $=4$ $38 \times 4=52 \mathrm{~cm}$

$152=2 \pi \mathrm{r}$

$\mathrm{r}=152 / 2 \pi$

$\mathrm{r}=25 \mathrm{~cm}$

Diameter of wheel $=50 \mathrm{~cm}$

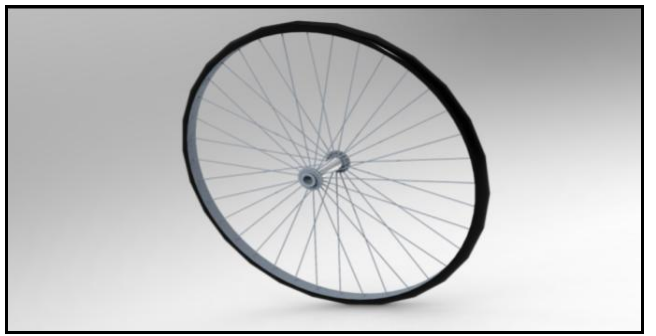

Fig.2 cycle wheel

Selection of sprocket (Deshpande, 2017)

$$
\begin{aligned}
& \frac{1}{3}=\frac{t_{p}}{t_{g}} \\
& \frac{1}{3}=\frac{18}{t_{g}} \\
& t_{g}=18^{\times} 3 \\
& t_{g}=54 \\
& \frac{t_{p}}{t_{g}}=\frac{D_{g}}{D_{p}} \\
& \frac{3}{1}=\frac{D_{g}}{72.5}
\end{aligned}
$$

$\mathrm{Pitch}={ }_{\text {pitcheirclediameterof pinion }}^{\text {numberoftethonpinion }}=\frac{18}{72.5}=0.25 \mathrm{~mm}$

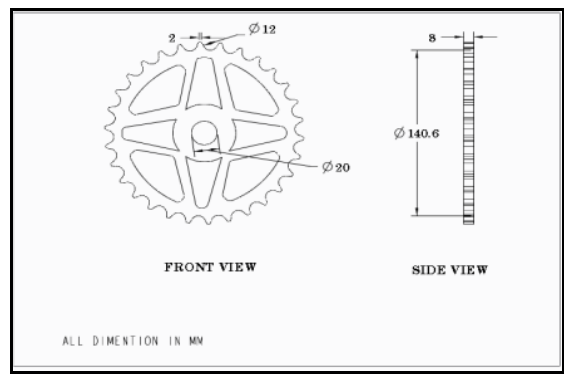

Fig.3 Gear
Selection of chain length (R.S. Khurmi, 2005)

Chain type roller ISO chain no.05B

pitch $=0.25 \mathrm{~mm}$

Length of chain, $=\mathrm{KP}$

No. of chain $=$

$\mathrm{K}=\frac{t_{1}+t_{2}}{2}+\frac{2 x}{p}+\left(\frac{t_{2}-t_{1}}{2 \pi}\right)^{2} \times \frac{p}{x}$

$\mathrm{K}=\frac{54+18}{2}+2 \times 479 / .25+\left(\frac{54-18}{2 \pi}\right)^{2} \times \frac{.25}{479}$

$\mathrm{K}=36+3824+0.00299$

$\mathrm{K}=3860 \mathrm{~mm}$

$\mathrm{L}=\mathrm{K} \times \mathrm{P}$

$\mathrm{L}=3860 \times 0.25$

$\mathrm{L}=965 \mathrm{~mm}$

$\mathrm{L}=96.50 \mathrm{~cm}$

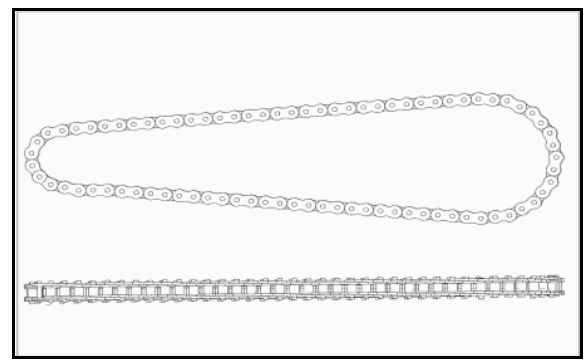

Fig.4 chain

Design of slider crank mechanism

Crank mechanism. A linear motion, back and forth, is transferred to a circular motion or vice versa. A rod is connected to a rotational crank, by moving the rod a circular motion is created. Alternatively, turning the rotational crank creates a linear motion.

Crank, $\mathrm{AB}=15.1 \mathrm{~cm}$

Connecting Rod, $\mathrm{BC} 1=10.8 \mathrm{~cm}$

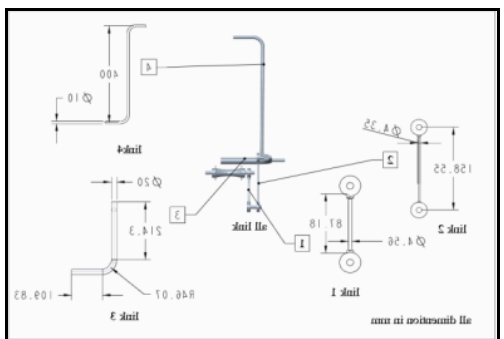

Fig.5 Crank assembly 
Determination of dimensions in the slider cranks mechanism

According to Grashof's law for a four bar mechanism, the sum of the shortest and longest link lengths should not be greater than the sum of the remaining two link lengths if there is to be Continuous relative



Fig.6 Free body diagram of the slider- crank at TDS and BDC position.

\section{Selection of bearing}

The roller contact consist of four part inner and outer faces a rolling element like ball, roller or needle and cage with hold the rolling element together and space them evenly around periphery



Fig.7 Bearing

\section{Selection of knapsack sprayer}

In manufacturing the sprayer a standard 16 litter knapsack sprayer were dismantled and the tank with piston pump integration is used

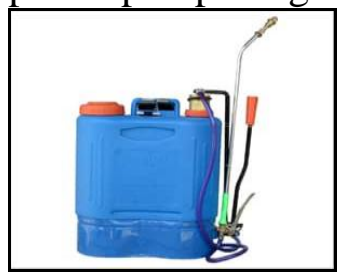

Fig.8 Knapsack sprayer

\section{Selection of shaft}

A drive shaft, driveshaft, driving shaft, propeller shaft (prop shaft), or cardan shaft is a mechanical component for transmitting torque and rotation, usually used to connect other components of a drive train that cannot be connected directly because of distance or need to allow for relative movement between them.

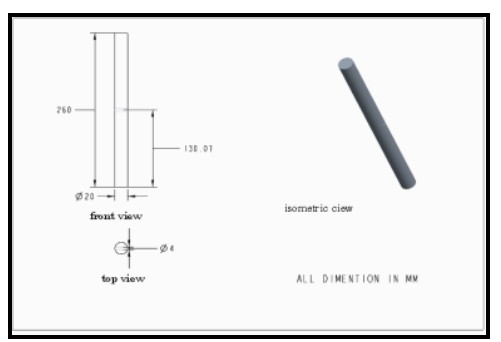

Fig.9 Front, top and isometric view of shaft.

\section{Selection of nozzle}

The spray angle does not hold for long spray distances. As illustrated in the figure below, the spray angle tends to collapse or diverge as you move away from the orifice. Theoretical coverage of spray patterns at various distances from the nozzle orifice is listed below.

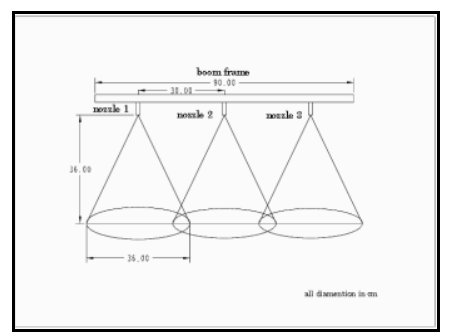

Fig.10 Sprayer pattern

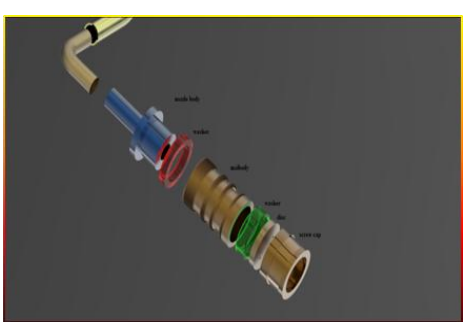

Fig.11 Dismantle part of nozzle 

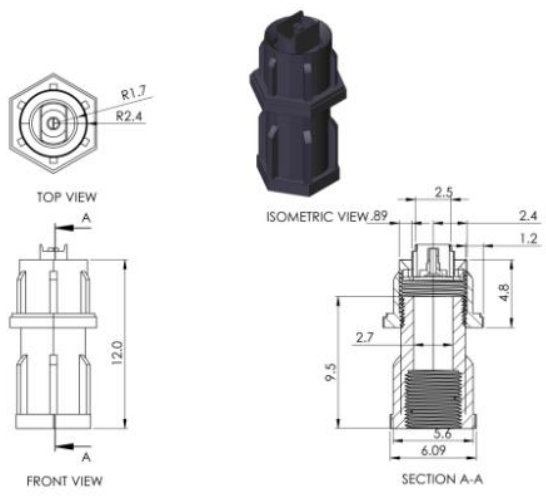

Fig.12 Dismantle part of nozzle

\section{Sprayer boom's pipe}

The boom is made of steel square pipe whose length is $90 \mathrm{~cm}$, outside length is $30 \mathrm{~mm}$ and inside diameter is $28 \mathrm{~mm}$. That means, distances between nozzles to nozzle is maintained by $30 \mathrm{~cm}$. It has three pieces, each of them $15 \mathrm{~cm}$ long, which are connected with nozzle holders. Both sides of each pipe are a taper with a ring.

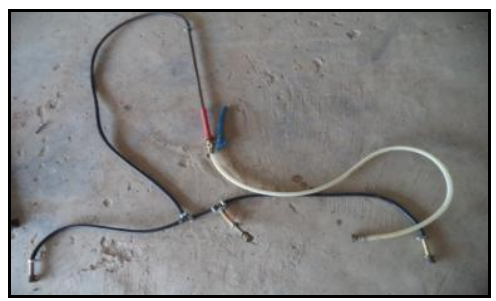

Fig.13 Sprayer boom's pipe

Design and development of the frame for holding the sprayer boom

A frame is made of MS bar. It is $100 \mathrm{~cm}$ long. This frame is fixed at the front of the implement main frame A holder is made on the bar rod is adjustable to distanced of nozzle to cover the crop as a required
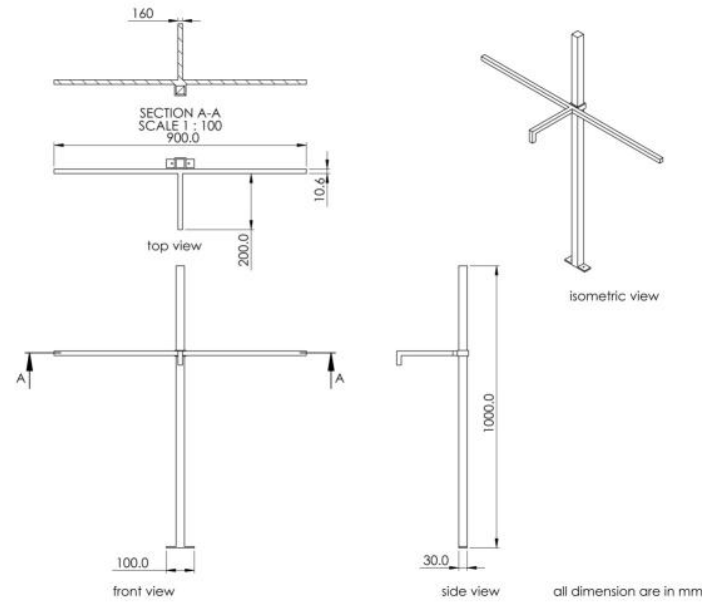

Fig.14 Line diagram of frame for holding the sprayer boom

Design and development of a frame for fixing the tank

A frame is made of MS flat bar (2 $\mathrm{cm} \times 0.3$ $\mathrm{cm})$ for fixing the tank with the main frame at the rear side. It is made to make a provision to set tank at the frame. The tank will be attached at the rear of the main frame to support the front and back of the tank during Spraying row vegetable crops,
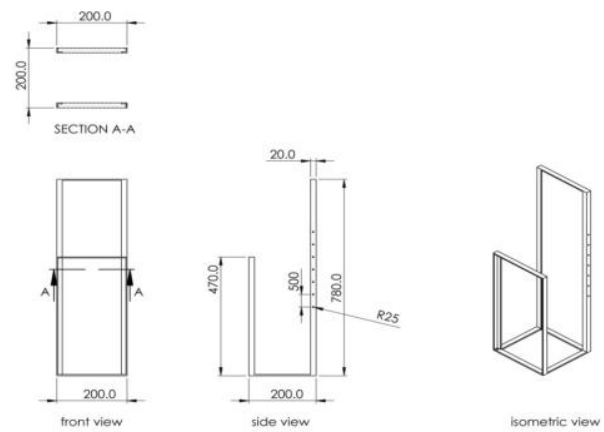

Fig.15 Line diagram frame to fixing the tank 


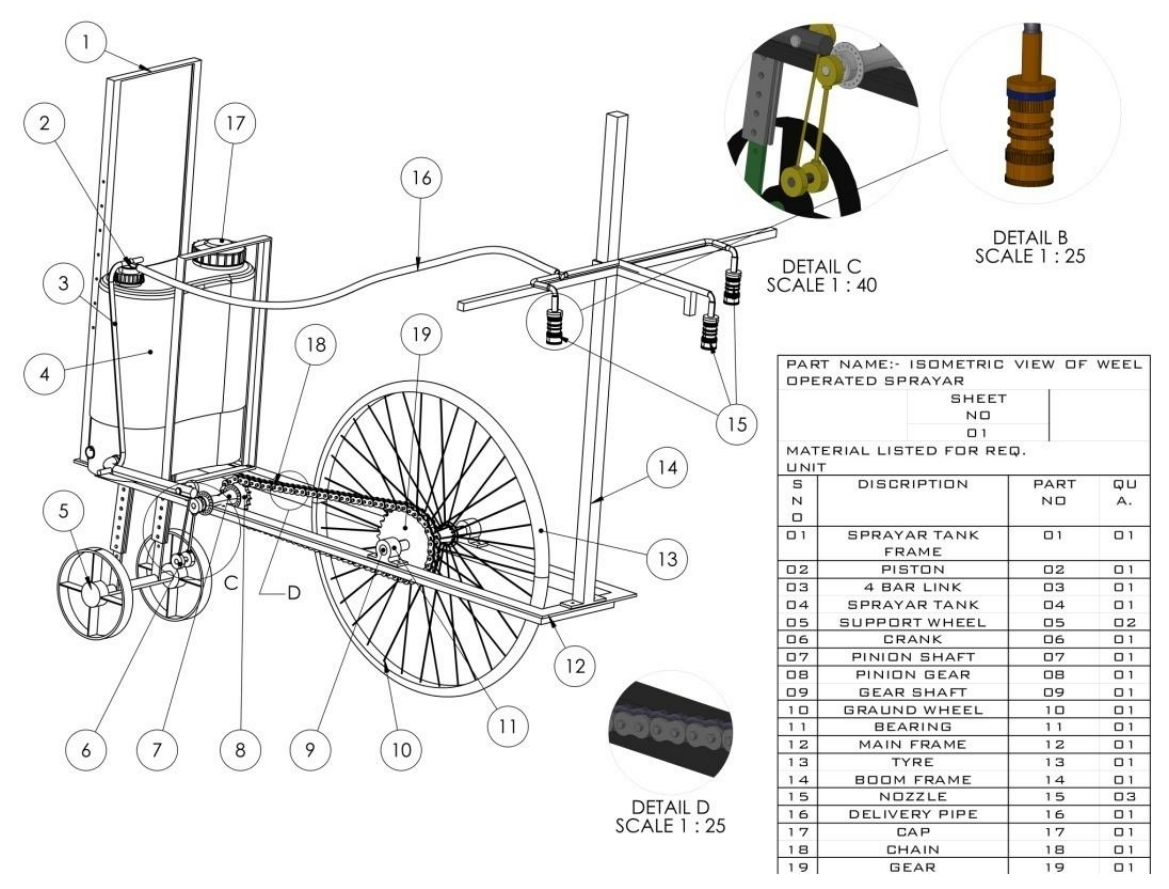

Fig.16 Entire assembly of mono wheel operated sprayer cum weeder

Pressure $=1$ to 3 bar (14.5-43.5 psi)

Area covered by each nozzle approximate 1.5

Field performance of mono wheel operated sprayer cum weeder

The developed wheel operated sprayer was evaluated in BRSM CAET \&RS Mungeli Farm, chickpea crop in the line sown of variety vaibhav-JG-30 month of November during crop season 2017-18, row to row spacing of $30 \mathrm{~cm}$ and plant to plant spacing randomly. The soil in the experiment site was clay soil, area of $100 \mathrm{~m}^{2}$ and.

The field tests were conducted at 15 days of crop age with height of plants ranging from 5$10 \mathrm{~cm}$. The different performances of sprayer test like speed of travel, field capacity, power requirement and performance index was calculated.

\section{Performance test}

The following observations were taken during the field test.

\section{Speed of operation}

Speed of operation of wheel operated sprayer cum weeder was measured the time required to cover $8 \mathrm{~m}$ distance. By recording speed was calculated by using following formula. (RNAM procedure)

Speed $(\mathrm{kmph})=\frac{3.6 \times \text { Distance traveled }(\mathrm{m})}{\text { time }(\mathrm{s})}$

\section{Power requirement}

Calculation of power is needed to determine the efficient use of man power. A man can produce power equal to 0.05 to $0.1 \mathrm{hp}$ operated for day long work. It was the power requirement to the implement by the man with average pushing force and speed. It was 
calculated by using the following formula (Michael and Ojha, 1966).

$$
\text { Power }(\mathrm{hp})=\frac{\mathrm{draft}(\mathrm{kg}) \times \mathrm{xspeed} \frac{\mathrm{m}}{\mathrm{g}}}{75} \ldots \ldots .
$$

\section{Theoretical field capacity}

Theoretical field capacity (Dubey, 2001)

$$
\left(h^{-1}\right)=\frac{5 \times W}{10}
$$

Where,

$\mathrm{S}=$ Speed of operation, kmph

$\mathrm{W}=$ Theoretical width covered and is equal to number of furrow openers multiplied by distance between two consecutive furrow openers

\section{Effective field capacity}

Effective field capacity (Dubey, 2001)

Where,

$$
\left(\mathrm{ha} \mathrm{h}^{-1}\right)=\frac{\mathrm{A}}{\mathrm{T}_{1}-\mathrm{T}_{\mathrm{z}}}
$$

$\mathrm{A}=$ actual area covered, ha

$\mathrm{T}_{1}=$ Total time require for operation, $\mathrm{h}$

$\mathrm{T}_{2}=$ non-productive time, $\mathrm{h}$

\section{Field efficiency}

It was calculated by using the following formula. (Dubey, 2001)

Field efficiency

$$
=\frac{\text { Effective field capacity }}{\text { theoretical field capacity }} \times 100 \ldots \text { (6) }
$$

\section{Nozzle discharge rate}

Nozzle discharge test was done to evaluate the amount of liquid discharge from each nozzle and to check the variation between the discharge rates of each nozzle within $5 \mathrm{~m}$ intervals in each $5 \mathrm{~m}$ interval the time taken and discharge data was collected and recorded for each nozzle by tying a plastic bag on each nozzle. After each $5 \mathrm{~m}$ interval the sprayer were stopped,

\section{Spray overlap}

The overlap is defined as the width covered by two adjacent nozzles divided by the width covered by a single nozzle, expressed in present. It mainly affects spray pattern of the sprayer it depends on the boom height and nozzle spacing below fig. Shown some parameter were taken during testing,

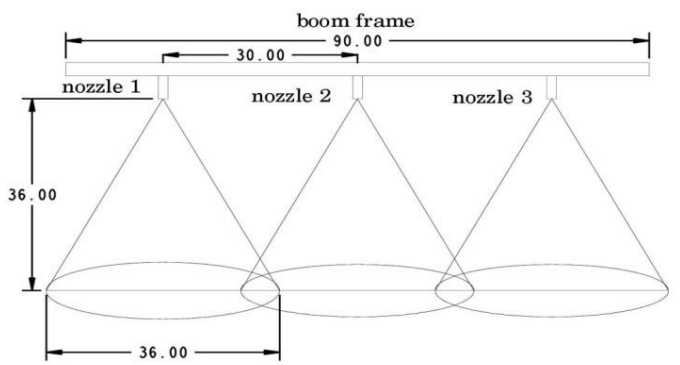

Fig.17 Sprayer overlap

\section{Results and Discussion}

The wheel operated sprayer is easy to operate due to cycle wheel as its ground wheel and The developed wheel operated sprayer used for line sown upland crops and vegetable crops, as row spacing can be adjusted. As far as physiological aspect is concern it is light in weight i.e. $30 \mathrm{~kg}$ and its handle height and angle of operation can be adjusted as per operator requirement.

\section{Discharge of sprayer}

During the discharge rate test in $15 \mathrm{~m}$ with $5 \mathrm{~m}$ interval of individual nozzle, the average nozzles discharge varies from 8.83 to $8.45 \mathrm{ml}$ $\mathrm{s}^{-1}, 11.63$ to $11.38 \mathrm{ml} \mathrm{s}^{-1}$ and 12.43 to $12.15 \mathrm{ml}$ $\mathrm{s}^{-1}$, with the average discharge of $8.63 \mathrm{ml} \mathrm{s}^{-1}$, $11.54 \mathrm{ml} \mathrm{s}^{-1}$ and $12.33 \mathrm{ml} \mathrm{s}^{-1}$ at the $1^{\text {st }}, 2^{\text {nd }}$ and $3^{\text {rd }} 5 \mathrm{~m}$ intervals respectively at a bar pressure of 1.8 bars. The coefficient of variation for the average of nozzle discharges was 0.01089 per 
cent, in $1^{\text {st }} 5 \mathrm{~m}, 2^{\text {nd }} 5 \mathrm{~m}$ and $3^{\text {rd }} 5 \mathrm{~m}$ respectively, of 10 per cent as per the recommendation which showed that the variation in discharges (Gomez and Gomez, 1984).

of the nozzle was below acceptable variation

Table.A Particular

\begin{tabular}{|c|c|c|}
\hline S.No & Particular & \\
\hline 1 & Name of implement & wheel operated sprayer \\
\hline 2 & Type of sprayer & Manually operated wheel operated \\
\hline 3 & Manufacturing's Address & BRSM CAET \&RS Mungeli, CG. \\
\hline 4 & Crop for Which suitable. & Chickpea, mustard, wheat, safflower. \\
\hline 5 & $\begin{array}{l}\text { Overall dimension in } \mathrm{mm} . \\
\text { Length: } \\
\text { Width: } \\
\text { Height: }\end{array}$ & $\begin{array}{l}1677 \\
900 \\
1394\end{array}$ \\
\hline 6 & Weight in kg. & $30 \mathrm{~kg}$ \\
\hline 7 & $\begin{array}{l}\text { Dimension of sprayer tank in, mm: } \\
\text { Length: } \\
\text { Width: } \\
\text { Height: }\end{array}$ & $\begin{array}{l}182 \\
369 \\
431\end{array}$ \\
\hline 8 & $\begin{array}{l}\text { Weight of applicator with and without } \\
\text { clean water of full tank } \\
\text { Capacity without a Discharge line } \\
\text { With water, kg. } \\
\text { Without water, kg. }\end{array}$ & $\begin{array}{l}19 \\
3\end{array}$ \\
\hline 9 & $\begin{array}{l}\text { Detail of handle } \\
\text { Construction: } \\
\text { Height of handle from ground level, } \mathrm{cm} \\
\text { Details of adjustment: }\end{array}$ & $\begin{array}{l}\text { Adjustment } \\
0-66.8 \text { to } 0-96.8 \\
\text { Adjustment through nut and bolt }\end{array}$ \\
\hline 10 & $\begin{array}{l}\text { Details of shank/ tool holder, } \mathrm{cm} \\
\text { Material: } \\
\text { Dimension: } \\
\text { Section- } \\
\text { Length- } \\
\text { Mounting details: }\end{array}$ & $\begin{array}{l}\text { Mild steel } \\
\text { Rectangle } \\
15 \\
\text { Angular hole, nut and bolt }\end{array}$ \\
\hline 11 & Tank capacity: 1 & 16 \\
\hline 12 & $\begin{array}{l}\text { Dimension of pump plunger, piston, or } \\
\text { diaphragm, } \mathrm{cm}\end{array}$ & $30 * 4$ \\
\hline 13 & Diameter of cylinder, mm & 40 \\
\hline 14 & Length of stroke, $\mathrm{mm}$ & 58 \\
\hline 15 & Mesh of strainer on pump inlet & 1 \\
\hline 16 & Type of nozzle as standard accessory & Fan type \\
\hline 17 & Ground clearance & 36.4(ground surface to main frame) \\
\hline 18 & Details of transporting system & Mono wheel as well as ground wheel \\
\hline 19 & Safety aspects & No required \\
\hline
\end{tabular}


Table.1 Discharge rate of individual nozzle in the $1^{\text {st }} 5 \mathrm{~m}$

\begin{tabular}{|c|c|c|c|c|c|}
\hline \multirow{2}{*}{ No of trail } & \multicolumn{3}{|c|}{ Discharge, $\mathbf{~ m l ~ s}^{-1}$} & Mean discharge in $\mathbf{~ m l ~ s}^{-1}$ & CV, \\
\cline { 2 - 4 } & \multicolumn{3}{|c|}{ Nozzle no } & $\%$ \\
\hline & $\mathrm{N} 1$ & $\mathrm{~N} 2$ & $\mathrm{~N} 3$ & & \\
\hline $\mathbf{1}$ & 8.45 & 8.63 & 8.83 & 11.54 & \\
\hline $\mathbf{2}$ & 11.38 & 11.63 & 11.61 & 12.33 & \\
\hline Average & 12.15 & 12.41 & 12.43 & 10.83 & 0.01089 \\
\hline
\end{tabular}

$\mathrm{N} 1, \mathrm{~N} 2, \mathrm{~N} 3$ are three flat fan nozzles fitted on the boom at $30 \mathrm{~cm}$ spacing

Table.2 Spray overlaps between nozzles

\begin{tabular}{|c|c|c|c|c|}
\hline \multirow{2}{*}{ DAS point } & \multicolumn{2}{|c|}{ Overlap in cm } & Mean average Overlap & CV \\
\cline { 2 - 4 } & N1-N2 & N2-N3 & & per cent \\
\hline At 5 m & 10.3 & 10.5 & 10.4 & \\
\hline At 10m & 10.4 & 10.2 & 10.3 & \\
\hline At 15m & 10.6 & 10.4 & 10.5 & 0.02 \\
\hline Average Overlap & 10.43 & 10.36 & 15.7 & \\
\hline
\end{tabular}

N1- N2 and N2-N3 are the adjacent three flat fan nozzles fitted on the boom at $30 \mathrm{~cm}$ spacing

Table.3 Discharge rate of individual nozzle in the field test

\begin{tabular}{|c|c|c|c|c|c|}
\hline \multirow{2}{*}{ Rep. } & \multicolumn{3}{|c|}{ Discharge, ml s } & Mean discharge & CV \\
\cline { 2 - 5 } & \multicolumn{3}{|c|}{ Nozzle no } & in ml s-1 & per cent \\
\cline { 2 - 5 } & $\mathrm{N} 1$ & $\mathrm{~N} 2$ & $\mathrm{~N} 3$ & 10.51 & \\
\hline $\mathbf{1}$ & 10.75 & 10.45 & 10.35 & 10.55 & \\
\hline $\mathbf{2}$ & 10.65 & 10.15 & 10.85 & 10.58 & \\
\hline $\mathbf{3}$ & 10.15 & 10.75 & 10.85 & 10.55 & 0.08 \\
\hline average & 10.51 & 10.45 & 10.68 & & \\
\hline
\end{tabular}

N1, N2 andN3 are three flat fan nozzles fitted on the boom at $30 \mathrm{~cm}$ spacing 
Table.4 Speed of travel of mono wheel sprayer cum weeder

\begin{tabular}{|c|c|c|c|c|}
\hline $\begin{array}{c}\text { Sr. } \\
\text { No }\end{array}$ & $\begin{array}{c}\text { Distance } \\
\text { covered }(\mathbf{m})\end{array}$ & Time (min.) & Speed (m/min.) & Average speed (m/min.) \\
\hline $\mathbf{1}$ & 10 & 0.36 & 27.8 & \multirow{2}{*}{28.2} \\
\hline $\mathbf{2}$ & 10 & 0.50 & 33.4 & \\
\hline $\mathbf{3}$ & 10 & 0.43 & 23.3 & \\
\hline
\end{tabular}

Table.5 Field capacity of wheel operated sprayer

\begin{tabular}{|c|c|c|c|c|c|}
\hline S.No. & Area, $\mathbf{~ m}^{\mathbf{2}}$ & $\begin{array}{c}\text { Time, } \\
\text { min. }\end{array}$ & $\begin{array}{c}\text { Actual field } \\
\text { capacity, ha/h }\end{array}$ & $\begin{array}{c}\text { Theoretical field } \\
\text { capacity, ha/h }\end{array}$ & $\begin{array}{c}\text { Field efficiency, } \\
\text { \% }\end{array}$ \\
\hline $\mathbf{1}$ & 100 & 8 & 0.075 & 0.126 & 59.52 \\
\hline $\mathbf{2}$ & 100 & 8.5 & 0.070 & 0.126 & 55.56 \\
\hline $\mathbf{3}$ & 100 & 9 & 0.067 & 0.126 & 53.17 \\
\hline
\end{tabular}

\section{Spray overlap}

During the spray overlap test in the average per cent overlap between the nozzles varies from 15.6 per cent to 15.7 at boom height of $30 \mathrm{~cm}$ and nozzle spacing of $30 \mathrm{~cm}$. which showed that the variation in overlap of the nozzle was within the range of $15-50$ per cent. The coefficient of variation (CV per cent) of percentage overlap between the nozzles were 0.02 per cent which shows very small variability of overlap between consecutive adjacent nozzles. These mean that the uniformity and coverage of the spray was good.

\section{Discharge rate of sprayer in field}

The field size, test duration, spray pressure, swath, discharge, speed of operation, field capacity and other relevant information were taken. The average discharge rate varies from 10.51 to $10.68 \mathrm{ml} \mathrm{s}^{-1}$ with the average discharge of $10.55 \mathrm{ml} \mathrm{s}^{-1}$ it was observed that at an operating pressure of 1.8 bars at the forward speed of $1.4 \mathrm{~km} \mathrm{~h}^{-1}$.

\section{Speed of travel of wheel operated sprayer}

The test was conducted by selecting a distance of $10 \mathrm{~m}$ and time for travel this distance was noted. Readings of travel speed were recorded and average speed of travel was calculated and presented in Table 4:

\section{Field capacity of wheel operated sprayer}

The average travelling speed was found to be $28.2 \mathrm{~m} / \mathrm{min}$. The field capacity was measured by selecting plots of size $10 \mathrm{x} 10 \mathrm{~m}$ and observations were recorded while operating the sprayer in these plots (Table 5).

\section{Conclusion}

Based on result above the sprayer has managed to maintain an average nozzle pressure of 1.8 bars during both the field and laboratory test at an average speed of $1.4 \mathrm{~km} / \mathrm{hr}$. The average nozzles discharge rate variation along travel distance reduced and attained an optimum discharge rate the nozzles $30 \mathrm{~m}$ distance.

The prayer is manufactured with tank capacity of 16 litters, a full tank can cover an area of 0.075 ha, which needs a refilling of 14 times to cover one hectare with an application rate of $638.09 \mathrm{l} / \mathrm{ha}$, an average discharge rate $10.55 \mathrm{ml} / \mathrm{sec}$. effective field capacity of 0.075 
ha/hr., it also has a good uniformity of coverage with an average percentage overlap of $15.7 \%$.

The sprayer forward speed and spray application are synchronized, so that once the sprayer attained the optimal uniform discharge along all the nozzles it will maintain its uniformity till the next tank filling. Moreover the sprayer applies the pesticide at about $3 \mathrm{~m}$ away from the operator, which minimized the chances of exposure of chemical to the operator and alleviates carrying the chemical tank at the back of the operator's shoulder.

\section{References}

Deshpande, S.V. 2017 Agricultural Reciprocating Multi Sprayer $7^{\text {th }}$ International Conferece on Recent In Trends in Engineering, Science \& Management ICRTESM-17, ISB: 97893-86171-12-2.

Khurmi, R.S. 2005. Text Book of Machine Design, Eurasia publishing house (pvt.) ltd. ram nagar, new delhi-110 055.
Gupta, V. 2005. Jhum Cultivation Practices of Bangnis (Nishis) of Arunachal Pradesh. Indian Journal of Traditional Knowledge. 4(1): 47 - 56.

Mulatu, Yonas. 2018 Fabrication and Performance Evaluation of Ground Wheel Operated Boom Sprayer International Journal of Engineering Research-Online A Peer Reviewed International Journal Vol.6. Issue. 3, 2018 May-June

Naik, R. K. 2018 Performance Evaluation of Manual Operated Single Wheel Weeder for Jute Crop, International Journal of Agricultural Engineering | Volume 11 | Issue 1 | April, 2018 | 49-53

Ojha, T.P. and Michael, A.M. 1966. Principles of Agricultural Engineering, Vol. 1, Jain Brothers. Third eds. 1996, pp : 1-10.

RNAM, 1995. Regional Network for Agricultural machinery, RNAM Test codes and procedure For Farm Machinery. : 171.

Singh P. K. Introduction to Weed Science and Challenges. CAFT on Agro-ecological Approaches towards Sustainable Agricultural Production from 01-21 Oct. 2013.

\section{How to cite this article:}

Shambhu Singh, D.Padhee, Suryakant Sonwani, Trishala Sahu. 2020. Design, Fabrication and Evaluation of Wheel Operated Sprayer. Int.J.Curr.Microbiol.App.Sci. 9(01): 1649-1659. doi: https://doi.org/10.20546/ijcmas.2020.901.182 